\title{
Islamic Psychotherapy for Children and Adolescents
}

\author{
Muhamad Afifudin Alfarisi \\ National Central University of Taiwan \\ email:alfarisi324@gmail.com
}

\begin{abstract}
The two great paradigms typically seen as two opposing are Islam and Psychology, which accumulate the cultural paradigm associated with mental health. Depending on the history, personality inside Islam and psychopathology has been present for centuries. Nowadays, Indonesia wellknown as a great Muslim population, which means, the need for mental health service among Muslim society is paramount. Arising awareness of mental health issues and services has increased in the use of mental health services. Therefore, it is substantial that the psychological society at richly understand how Islamic principles can be integrated into psychotherapy. This observation tries to outlining strategies to incorporate the Islamic values into psychotherapy with adults, which the research concerning utilizing Islamic psychology principles with children and adolescents not properly utilizing.
\end{abstract}

\section{Keywords: Islam; psychology; psychotherapy; children; adolescents}

\begin{abstract}
Abstrak: Dua paradigma besar yang biasanya dilihat sebagai dua lawan adalah Islam dan Psikologi, yang mengakumulasi paradigma budaya yang terkait dengan kesehatan mental. Bergantung pada sejarah, kepribadian dalam Islam dan psikopatologi telah ada selama berabad-abad. Saat ini, Indonesia yang terkenal sebagai populasi Muslim yang besar, yang berarti, kebutuhan akan layanan kesehatan mental di kalangan masyarakat Muslim adalah yang terpenting. Timbulnya kesadaran akan masalah dan layanan kesehatan mental telah meningkat dalam penggunaan layanan kesehatan mental. Oleh karena itu, sangat penting bahwa masyarakat psikologis pada kaya memahami bagaimana prinsip-prinsip Islam dapat diintegrasikan ke dalam psikoterapi. Pengamatan ini mencoba untuk menguraikan strategi untuk memasukkan nilai-nilai Islam ke dalam psikoterapi dengan orang dewasa, yang penelitian tentang penggunaan prinsip-prinsip psikologi Islam dengan anak-anak dan remaja tidak memanfaatkan dengan benar.
\end{abstract}

Kata Kunci: Islam; psikologi; psikoterapi; anak-anak; remaja 


\section{A. Introduction}

The youth age such Adolescents is a period that is bound culturally. In the Indonesia, the end of adolescents defined by legal markers as one is seen as an adult at the age of eighteen. However, the time of adolescents seems more fluid concept, and it is passages such as marriage defined by the traditional rites. Adolescents period is a time to exploring the identity of his/her values as well as occurring the formation. Basically, seems as a period of stress and storm as well as conflict with progenitor. This conflict regarding values and it is accentuated occur when there in a difference in religious values between parents and children periodically. Therapist task is consistently observed between parent and children middle grounds.

At the initial age such Children, naturally filter the information flows from their parents and other adults; thus, affect adults in their lives change their religious values. Children understanding of religious mores and values is quite related upon his or her establishment and cognitive quality. Regarding Piaget (1936), a child who is in the preoperational level of development might see religion as black or white, little gray area room, whereas a child who is in the formal operation level may be propose the abstract reason and explain information in a more complex thing to his or her own opinion forms. ${ }^{1}$

Islamic identity regularly education transfer from parent to their children, upbringing and gradually establish their sense of Muslim characters. Furthermore, in the mass cultures, the ancestor and other extended family members are also responsible for past through on religious values and behavioral circumstances. Parents may also attend their pupils in long-day, or religious education courses in weekend to enhance their pupil's education. At this period, peer seems might be one's values affected by them. Teenagers in particularly, peers may also continuously become influential than parents. In addition, this might be can extend to understanding the morality (right and wrong).

The crucial things of the family system in the Islamic tradition are consistently prioritized over the individual needs, concern to the natural therapy with children and adolescents as a part system of family. Despite this, psycho-

1Jean Piaget, The Origins of Intelligence in Children, ed. Margaret Cook (New York: W W Norton \& Co, 1952), 380. https://doi.org/10.1037/11494-000. 
therapy would be advantages, certainly presenting key challenges. This paper discusses the integration between psychotherapy in Western terms to the Islamic principles with children, adolescents, and families and the potential challenges in involving of large Muslim society. Moreover, will negotiated challenges and suggestions for psychotherapy for system establishment.

\section{B. Islam and Islamic Psychology}

Islam is religion with monotheistic that began seventh century with prophet Mohammed deliver the words of Qur'an. Qur'an believed by all of Muslim as Holy Book and embrace a complete way of life, including domain in socio-political. Field domain such sharia (Islamic law), corporate many Muslimmajority countries, therefore, leaving quite a room for separation of state and religion. Islam holds that followers must obey the right path in order to obtain a righteous and life in fulfill. ${ }^{2}$

Islam serve as the primary principles of faith which is Five main pillars. First of all, Declaration of faith (shahadah) is the initial pillar and contains the only word required for an individual to become a Muslim. The second pillar is five times prayer (salāt), the muslim obligation to supplicate five times a day benediction. The third pillar zakat, hold 2.5 percent of they were saving annually to those who need. The fourth pillar, fasting (sawm), necessitate individuals to abstains from drink, food, and sexual activity during the holy Ramadan. The fifth pillar of Islam, is pilgrimage to Mecca (hajj), that the complete faith at least once in their lifetime if they are able to financially afford it. ${ }^{3}$

Muslim are also prescribed style of life requirements to which they must adhere more than basic tenets of Islam. Such, include abstaining from foods forbidden (haram) or foods that contains of pork-based products. Alcohol is also prohibited in Islam. In the context of relationships, is also separated between males and females, with intermix between the sexes not generally condoned unless it is for academic purposes. In addition, community handle great

\footnotetext{
2Fariyal Ross-Sheriff and Altaf Husain, "South Asian Muslim Children and Families," in Culturally Competent Practice with Immigrant and Refugee Children and Families, ed. R. Fong (New York: Guilford Press, 2004), 163-82.

${ }^{3}$ Pete Seda, Islam Is ...: An Introduction to Islam \&amp; Its Principles (Pakistan: The English Language Section of Department of Islamic Resources, 2002), https://islamhouse.com/en/books/ 1301/.
} 
importance in Islam, and Islam promotes the interconnectedness of family. The community prayer in Friday, undertake in mosque (masjid) which is a holy day for Muslims. ${ }^{4}$

The Islamic psychology, although author try to discuss the intersection between Islam and psychology. The lack of articulation of a definition of Islamic psychology has been discussed by York al-Karam with reference to many authors previously. Her analyze, trying to conceptualizes the discipline of Islamic psychology by way of multilevel paradigm as "the interdisciplinary space where psychology, sub-disciplines, or related disciplines involve a particular scientific topic and a particular level with different Islamic sect., sciences, sources, school of thought using a variety of methodological tools". Delineate on the discussion York al-Karam proposed, Islamic psychology tendency to an understanding of human nature and the psyche build upon the early work of Muslim scholars as well as philosopher that interplays with psychology and psychotherapy in Western terms. ${ }^{5}$

Muslim scholar, such al-Ghazali (1058-1111) remarks the notion of ilm-alnafs (science of the self), well known in western as psychology. He argued that the self or psyche (nafs) comprises many states; nafs al-mutmainna (the calm and peaceful self, nafs al-ammarah (the ordering self), nafs al-lawwama (the blaming and evaluating). ${ }^{6}$ Nafs is term sometimes used interchangeably with soul (ruh), which means encompasses drives, feelings, thought, behaviors, and will. The ruh, also referred to as the "spirit of man"7 either drives a person away from the will of Allah or closer to him. The use of 'aql or 'ilm (intellect and knowledge) the individual is able to distinguish between good will and evil direct his or her circumstances toward the will of Allah. The innate tendency it is posited human behavior driven by fitrah to believe in the oneness of Allah (tawhìd) and worship. Henceforth, the cognition not only understood within the

4Saxby Pridmore and Mohamed Iqbal Pasha, "Psychiatry and Islam," Australasian Psychiatry 12, no. 4 (2004): 380-85, https://doi.org/10.1080/j.1440-1665.2004.02131.x.

5York al-Karam, "Islamic Psychology: Defining a Discipline," in Paper for Seminar at Center for Islamic Legislation, 2017, https://www.cilecenter.org/en/news/call-papers-islamic-psychologydefining-discipline/.

${ }^{6}$ Akbar Husain, Islamic Psychology: Emergence of a New Field (New Delhi: Global Vision Publishing House, 2006).

${ }^{7}$ Hooman Keshavarzi and Amber Haque, "Outlining a Psychotherapy Model for Enhancing Muslim Mental Health Within an Islamic Context," International Journal for the Psychology of Religion 22, no. 3 (2013): 230-49, https://doi.org/10.1080/10508619.2012.712000. 
physical brain but also within the qalb (heart). The essential for following the pathway of Allah is qalb. It is manifest as the source of spiritual disease and unrest. Al-Ghazali differentiate between the physical body and self-spiritual; physical body is composed of flesh, which is the spiritual aspect of the self is the essence of human, and the center is a heart.

\section{Mental Disorder}

Regarding to an Islamic scholar, mental disorder (psychopathological) disease appear from an imbalance between the spiritual needs and worldly. AlGhazali's also descibed that psychopathological illness as resulting from the spiritual distance from Allah. Disease inside the qalb are bring about disease, including ignorance, envy, cruelty, lust, cowardice, malevolence, deception and greed, that the conditions viewed as deviations from the will of Allah. ${ }^{8}$ The disease are result of evil tendency of the nafs, dormancy of the aql and sometimes lack of good reason. ${ }^{9}$ Furthermore, misusing the choice and freedom given by God (Allah) can result in undesired symptoms. From Islamic psychological perspective, self is conflict and must be balanced in order to obtain a well-adjusted sense of self. The final result willing to obtain in Islamic psychology is to have the nafs reach unconditional tranquility (nafs almutmainna) whereas the sick psyche is addressed to as nafs-al-marid..10 The Qur'an and Hadith in Islamic psychology set bound and limit, and the aim to help individuals back to the right way.

\section{Cognitive Behavioral Therapy}

Western developed therapeutic approach which are called Cognitive behavioral therapy (CBT) that posits thought or beliefs, behavior and emotions are interconnected. At this sense, it holds the way of individual interprets a circumstance affects such feels and act of human being. By using CBT, error in the way of person's thinking are identified. Moreover, maladaptive thought are challenged and reframed with the adaptive thought as well as behavior. The key

\footnotetext{
${ }^{8}$ Husain, Islamic Psychology: Emergence of a New Field.

${ }^{9}$ Keshavarzi and Haque, "Outlining a Psychotherapy Model for Enhancing Muslim Mental Health Within an Islamic Context."

${ }^{10}$ Hisham Abu-Raiya, "Working with Religious Muslim Clients: A Dynamic, Qura'nic-Based Model of Psychotherapy," Spirituality in Clinical Practice 2, no. 2 (2016): 120-33, https://doi.org/ $10.1037 /$ scp0000068.
} 
of CBT strategy including collaborative relationship establishment between the therapist and the client, in common plan set by the Socratic questioning, clinical, homework, and cognitive restructuring. ${ }^{11}$

In the 1977, Urie Bronfenbrenner ${ }^{12}$ was developed the mesosystem which is theory put that an individual interact with four ecological systems influence to the children or adolescent cultivation. Including microsystem which comprise the individual's immediate surroundings, relationship with parents. The mesosystem refers to the interactions between the individuals who make up the mesosystem such as the interactions between individual's parents and school, which impacting to the child directly. The macro-system refers to the cultural and societal beliefs, including religion. The ecological system as well as CBT that the system function in harmony, suitable on context in CBT. ${ }^{13}$

\section{E. Suitability system of ecological theory with Islam}

Islamic psychology seems contrast with Western psychology necessarily the critical arguments address to the Western psychology aim to rationalize guilt and prefers individualistic.14 The other aspect is fit with psychotherapy in context of Islam it might be CBT. The research delineated by Beshai, Clark, and Dobson that the points of conflict between Islam and CBT as far as CBT can suitable to fit one's religious values. The authors see, Islamic more rationalistic rather than constructivistic. There are absolute truths and "should" statements such should pray five times a day, yet in CBT, the word "should" statements are avoided. ${ }^{15}$ In the other hand, there are several issues with a hypothesis examination as several issues might be wrong in Islam, for instance such Homosexuality, or consuming alcohol. Further, attempting to rationalize a

\footnotetext{
${ }^{11}$ Michelle J. Pearce et al., "Religiously Integrated Cognitive Behavioral Therapy: A New Method of Treatment for Major Depression in Patients with Chronic Medical Illness," Psychotherapy 52, no. 1 (2015): 56-66, https://doi.org/10.1037/a0036448.

${ }^{12}$ Elizabeth A. Zierten and Livia L Gilstrap, "Urie Bronfenbrenner," Encyclopaedia Britanica, accessed January 15, 2019, https://www.britannica.com/biography/Urie-Bronfenbrenner.

13Urie Bronfenbrenner, "Toward an Experimental Ecology of Human Development," American Psychologist32, no. 7 (1977): 513-31, https://doi.org/10.1037/0003-066x.32.7.513.

${ }^{14}$ Mumtaz F. Jafari, "Counseling Values and Objectives: A Comparison of Western and Islamic Perspectives," 1993.

${ }^{15}$ Shadi Beshai, Cameron M. Clark, and Keith S. Dobson, "Conceptual and Pragmatic Considerations in the Use of Cognitive-Behavioral Therapy with Muslim Clients," Cognitive Therapy and Research37, no. 1 (2013): 197-206, https://doi.org/10.1007/s10608-012-9450-y.
} 
client's guilt from consuming alcohol could be contrasting with productive life. It also complicated to deal with cognitive maladaptive system that are radically in Islamic values. In the Islamic terms, believed all of the positive phenomena as well as all embedded originate from Allah, can posits the Muslim client into the adaptive circumstances whereas not controlled. In this sense, CBT contrast with an idea aims to recharges the individual by reinforcing the idea that the human has control over his or her behavior, thinking, and environment. ${ }^{16}$

Hodge and Nadir for instance, provide how the traditional CBT statements can flexibility change in an Islamic perspective. As an example, the status quo "Because I consistently placed myself undisciplined and defeat-myself by demanding that I absolutely should have gratification quickly, I can give up my short-range 'needs' — look for the pleasure of today and tomorrow and seek life satisfaction in a disciplined way" can be changed to Allah (God) gave us free will as well as ability to control the the nafs (self). ${ }^{17}$ In the other hand, Allah gave us opportunity to controlling the body and mind by using fasting during ramadan, also the way to drive the nafs for the better life.

\section{F. Defiance of Islamic View Involve Age periods and recommendations for a way of Islamic Psychotherapy}

The challenges would like to explain that there are systemic and contextual constraints as well as unique experience. Being a Muslim psychotherapy in terms of contextual restricted in a hospital setting whereas there is unstructured for implementing the Islamically oriented psychohterapy. This is recommended to be implemented as the specified guidelines for engaging with Muslim clients.. Furthermore, the ethical issues of the level to which religion is incorporated into psychotherapy might be slightly concern in a Muslim client sets. No branded as "Muslim psychologist", it may clients would not convenient, instead, be kind for all clients might be comfortable while discussion for clinical disease.

The integrative approach in which conceptualization and also treatment are based on psychotherapy from Western approach assimilate with an Islamic

\footnotetext{
16Beshai, Clark, and Dobson.

${ }^{17}$ David R. Hodge and Aneesah Nadir, "Moving toward Culturally Competent Practice with Muslims: Modifying Cognitive Therapy with Islamic Tenets," Social Work (Oxford University Press, 2008), https://doi.org/10.2307/23721187.
} 
principles into the treatment. As an ideal treatment, Islamic approach to psychotherapy would initiate and enhance from the ground, where both of the concept and treatment occur through Islamic philosophical views. Keshavarzi and Haque outlined an Islamic psychotherapy in which intervention at the three stage of the self: ruh, nafs, and aql.18 The therapeutic are based on cognitive therapy such as reframing and positive religious self-talk with interconnection with spirituality.

A dynamic layout has shown by Abu-Raiya, in view of Quranic model psychotherapy which is psychodynamic as a basic hypothesis. The insubordination of setting up an Islamic psychotherapy approach is the absence of preparing given in the profound issue all in all medical clinic programs. The inadequacy of perception of crafted by Islamic researcher accounts for only a cursory understanding of the Islamic theory of personality. ${ }^{19}$

As which has been explained, there has been movement in conceptualizing through an Islamic psychology views and the improvement of personality understanding in Islam. Furthermore, an Islamic philosophical knowledge must be attained in order to adequately create a strategy of intervention that is radical and contextualized from an Islamic psychological viewpoint.

\section{G. Closure: Future of Islamic Psychotherapy}

The conflict and limitation in integrating Islamic principles into psychotherapy with some suggestions is constitute a challenge. First steps that possible to improve such as incorporate standardized measure of religious affiliation and further understanding the one's religious beliefs during therapy. Another development would be to serve psychoeducation on the integrative Islamic psychology approach and integrated into psychotherapy. Further, the measure of therapy has greatly been tendencies on qualitative measures and subjective self-reports. On the other hand, having a direct relationship with an Imam or other religious scholar would be helpful to organize treatment. Also, suggest others refers to spiritual leader for consultation on matters that are difficult to analyze in clinical. In another suggestion is further education and awareness to

\footnotetext{
${ }^{18}$ Keshavarzi and Haque, “Outlining a Psychotherapy Model for Enhancing Muslim Mental Health Within an Islamic Context."

${ }^{19}$ Abu-Raiya, "Working with Religious Muslim Clients: A Dynamic, Qura'nic-Based Model of Psychotherapy."
} 
the Muslim society concerning to mental health issues, particularly those impacting children, adolescents, to enhance utilization of mental health services. Henceforth, it is fundamental that education be spreading in worship places and schools, also parenting groups aware with sign for issues of mental health.[s]

\section{References}

Abu-Raiya, Hisham. "Working with Religious Muslim Clients: A Dynamic, Qura'nicBased Model of Psychotherapy." Spirituality in Clinical Practice 2, no. 2 (2016): 120-33. https://doi.org/10.1037/scp0000068.

Ali, Saba Rasheed, William Ming Liu, and Majeda Humedian. "Islam 101: Understanding the Religion and Therapy Implications." Professional Psychology: Research and Practice 35, no. 6 (2004): 635-42. https://doi.org/10.1037/07357028.35.6.635.

Beshai, Shadi, Cameron M. Clark, and Keith S. Dobson. "Conceptual and Pragmatic Considerations in the Use of Cognitive-Behavioral Therapy with Muslim Clients." Cognitive Therapy and Research 37, no. 1 (2013): 197-206. https://doi.org/ 10.1007/s10608-012-9450-y.

Bronfenbrenner, Urie. "Toward an Experimental Ecology of Human Development." American Psychologist 32, no. 7 (1977): 513-31. https://doi.org/10.1037/0003066x.32.7.513.

Hodge, David R. "Spiritually Modified Cognitive Therapy: A Review of the Literature." Social Work51, no. 2 (2006): 157-66. https://doi.org/10.2307/23721280.

Hodge, David R., and Aneesah Nadir. "Moving toward Culturally Competent Practice with Muslims: Modifying Cognitive Therapy with Islamic Tenets." Social Work. Oxford University Press, 2008. https://doi.org/10.2307/23721187.

Husain, Akbar. Islamic Psychology: Emergence of a New Field. New Delhi: Global Vision Publishing House, 2006.

Jafari, Mumtaz F. “Counseling Values and Objectives: A Comparison of Western and Islamic Perspectives," 1993.

al-Karam, York. "Islamic Psychology: Defining a Discipline." In Paper for Seminar at Center for Islamic Legislation, 2017. https://www.cilecenter.org/en/news/callpapers-islamic-psychology-defining-discipline/. 
Keshavarzi, Hooman, and Amber Haque. "Outlining a Psychotherapy Model for Enhancing Muslim Mental Health Within an Islamic Context." International Journal for the Psychology of Religion 22, no. 3 (2013): 230-49. https://doi.org/ 10.1080/10508619.2012.712000.

Pearce, Michelle J., Harold G. Koenig, Clive J. Robins, Bruce Nelson, Sally F. Shaw, Harvey J. Cohen, and Michael B. King. "Religiously Integrated Cognitive Behavioral Therapy: A New Method of Treatment for Major Depression in Patients with Chronic Medical Illness." Psychotherapy 52, no. 1 (2015): 56-66. https://doi.org/10.1037/a0036448.

Piaget, Jean. The Origins of Intelligence in Children. Edited by Margaret Cook. New York: WW Norton \& Co, 1952. https://doi.org/10.1037/11494-000.

Pridmore, Saxby, and Mohamed Iqbal Pasha. "Psychiatry and Islam." Australasian Psychiatry 12, no. 4 (2004): 380-85. https://doi.org/10.1080/j.14401665.2004.02131.x.

Ross-Sheriff, Fariyal, and Altaf Husain. "South Asian Muslim Children and Families.” In Culturally Competent Practice with Immigrant and Refugee Children and Families, edited by R. Fong, 163-82. New York: Guilford Press, 2004.

Seda, Pete. Islam Is ...: An Introduction to Islam \&amp; Its Principles. Pakistan: The English Language Section of Department of Islamic Resources, 2002. https://islamhouse.com/en/books/1301/.

Zierten, Elizabeth A., and Livia L. Gilstrap. "Urie Bronfenbrenner." Encyclopaedia Britanica. Accessed January 15, 2019. https://www.britannica.com/ biography/Urie-Bronfenbrenner. 
STACK :

/BuildT3EuroFont 